\title{
Study of Mobile City Application in Indonesia
}

\author{
Alifia Nada Putri Galuh ${ }^{1}$, Rini Rachmawati
}

Received: $15^{\text {th }}$ July 2020

Accepted: $18^{\text {th }}$ September 2020

\begin{abstract}
The Implementation of e-government has been established with the Instruction of President. Application of e-government is a research topic that has received a lot attention because of its improve the function and management of the city by utilizing Information and Communication Technology to improve the quality of public services. In this research focused on one application of e-government that called Mobile City. This study observe 22 application that has been implemented in 22 regencies/cities. This study have goals to identify and compare all 22 Mobile City Applocation to get the rank of the City/Regency based on the quality of its application and research city with the best application. The results of the study to show the Mobile City application applies a Location Based Services (LBS) system so the main features of this application showed tourism locations or public facilities. The difference of application features between regencies/cities is depends on how the City/Regency developed their application. The city that has the most complete features on its mobile city is Surakarta that called Solo Destination. This application is managed by the Office of Infromation Communication Statistics and Coding of Surakarta City with the most frequently used feature is community complaints.
\end{abstract}

Keywords: city application, smar city, e-government

\section{INTRODUCTION}

Progress of Information and Communication Technology (ICT) now it was grows rapidly in any sectors, such as in economic services such as (e-shopping) and electronic payment (e-banking)(Rachmawati et al., 2015). Progress of ICT give an impact to government sector that the government use ICT to make an innovation (Hapsari \& Rachmawati, 2018), beside that ICT in government can use to develop the city/regency and solve the city/regency problem Information, Communication, and Technology (ICT). ICT provide convenience to government, private companies, and society to give or get the information. ICT forced the government to make a public services integrated with ICT. Public services that integrated with ICT was one of smart city/smart regency implementation that has an emphasis on the use of appropriate technology. City/Regency that is moving to smart city of course need an city application to facilitate the government and public activity. Beside that, city application can use to solve the City/Regency problem and make high quality of services public. Public Services that integrated with ICT enables people to access the services and information without any mobility and make the public services efficient (Rachmawati, 2012). Indonesia was preparing smart cities through the Program Toward 100 Smart Cities that organized by the Ministry of Communication and Information Technology (Rachmawati, 2019). Both city authorities and information and communication technology (ICT) companies are responsible for finding the best

\footnotetext{
${ }^{1}$ Urban Development Research Group, Department of Development Geography, Faculty of Geography, Universitas Gadjah Mada
} 
methods and technologies to ensure the sustainability of future megacities, an important role is played by how data are gathered, stored, and accessed (Radu, 2020). The description of smart cities is heterogeneous and commonly agreed facets converge sustainability, ICT -based technology, and community needs (Ahmadi-Assalemi et al., 2020). To develop the application, big data has an important role to smart city. Smart cities can be achieved by combining available resources, such as government data and sensor networks deployed in cities, with city knowledge in the form of the citizens active contribution of data by means of their smartphones (Aguilera et al., 2017).

Mobile City Application or it called mCity is application that support e-government. This application implemented in 22 City/Regency in Indonesia that have different name in each City/Regency such as Lebong Regency is Lebong dalam Genggaman, Batu City is Shining Batu, Magelang City is Magelang Cerdas, Pariaman City is mCity Pariaman, Kudus Regency is Kudus, Denpasar City is Denpasar Sightseeing, Magelang Regency is Pesona Magelang, Karanganyar Regency is Awesome Karanganyar, Palembang City is mCity Palembang, Kendal Regency is Visit Kendal, Rokan Hulu Regency is Rohul Smart Access, Belitung Timur Regency is Visit Beltim, Sleman Regency is Amazing Sleman, Batu Bara Regency is Pesona Batu Bara, Demak Regency is Ayo ke Demak, Sragen Regency is Sragen Toursm, Rembang Regency is Rembang Bangkit, Surakarta City is Solo Destination, Purbalingga Regency is Smart City Purbalingga, Wonogiri Regency is Smart City Wonogiri, Tangerang Selatan City is Tangsel Cmore City, and Yogyakarta City is Jogja Istinewa (mCity, 2017).

The Implementation of e-government has been established with Instruction of the President of the Republic of Indonesia Number 3 of 2003 Concerning National Policy and Strategy e-government development. Indonesia is currently experience a change of life towards a democratic system, transparent, and laying the rule of law. E-government development is an effort to develop governance based ICT to improve quality of public services effectively. Beside that, ICT can improve city function and management that realized with e-government (Rachmawati et al., 2018). The implementation of ICT can be use in public services that provided by government and produce public services based on ICT which is one of smart city implementation (Rachmawati et al., 2018). Smart city is the aspects of city management, every city/regency has their own problem. With smart city it can be alternative/innovative to solve the problem with ICT but the most important steps to start Smart City is to identify the needs and priorities of city problems (Rachmawati, 2019).

Mobile City application or it called by mCity is an city application in the form of digital information portal and mobile application that have function as public servives directory an city branding made by Gamatechno. The growth and development of ICT resulted in a grow of smartphone users, by using smartphones it will have many conveniences. This can be used as an opportunity by the district / city government to improve public services. The Mobile City application uses the Location-Based Services (LBS) system. LBS is an information service that can be accessed through mobile devices that have the ability to utilize the location of mobile devices, so they can find out the location of a tourism destination or public facility. But to find out whether an application can function properly it is necessary to examine the quality of the software. LBS is the application of how geospatial technologies and geoinformation use in an application/software. Geospatial technologies and geoinformation could play a important role in smart city environments (Daniel \& Doran, 2013).

Mc Call, et al (McCall, Jim A and Richards, Paul K and Walters, 1977) provide a theory of software quality that focuses on three important aspects of a product, namely (1) Product operational characteristics (Product Operation), which include: a) Correctness which means functionally in accordance with product specifications, b) reliability that 
serves to assess the extent to which the application system will error / fail, c) usability, which assesses the ease of use of the application, d) integrity (integrity) related to the security and privacy of users; e) efficiency (efficiency) sees the use of application resources such as memory, network. (2) Product Transition is the application's ability to change which includes: a) Portability (Portability) measuring Software adaptability; b) The ease of use of software in different contexts; c) Interoperability (Interoperability) to what extent the software components can work together. And (3) Product revision that assesses the ability of the application to adapt includes: a) Maintainability, namely the ability to find and repair damaged applications; b) Flexibility (Flexibility) regarding changes that are needed at any time according to certain circumstances; c) Testability the ability to be tested to validate application requirements and ensure that the program can perform functions as expected.

\section{METHOD}

This research use qualitative and quantitative method. Data collected by using indepth interview techniques and roaming applications. The in-depth interview was conducted with one of the mobile city application managers in one of the districts / cities that has the most complete features. Data processing explained with descriptive statistics to assess features and simple scoring to rank mobile city applications in each district / city based on the features they have. This research was conducted in 22 districts / cities that have mobile city applications. This research was conducted in 22 districts / cities that have mobile city applications such as Batu Bara Regency, Belitung Timur Regency, Demak Regency, Karanganyar Regency, Kendal Regency, Kudus Regency, Lebong Regency, Magelang Regency, Malang Regency, Rembang Regency, Rokan Hulu Regency, Sleman Regency, Sragen Regency, Wonogiri Regency, Batu Ciry, Denpasar City, Magelang City, Pariaman City, Surakarta City, Tangerang Selatan City, Yogyakarta City. The analysis technique used quantitative-qualitative descriptive analysis techniques. Then one district / city was chosen which has the most complete features with a simple scoring process. One of these districts / cities that has the most complete features is Surakarta City with the application name is Solo Destination.

\section{RESULTS AND ANALYSIS}

The Mobile City application uses the Location-Based Services (LBS) system. LBS is an information service that can be accessed through mobile devices that have the ability to utilize the location of mobile devices, so they can find out the location of a tourist destination or public facilities. This resulted in the main features of the Mobile City application relating to the location of tourism and public facilities

\section{Mobile City Application Features}

In general, the first appearance when opening the Mobile City application will show the characteristics of a district / city (Figure 1). After the application opens, the application's initial display will appear, which has four main menus, namely Home, Nearby, Event, and More. The home menu consists of various information and features ranging from weather and temperature information, to the main destinations that are displayed in highlight mode which when clicked, information will appear regarding the tourist location starting from distance, description, to review of the tourist location. Not only Highlight mode has that information.

The features on the home menu that provide information about the location of a place when choosing one location will show three information it was description, location, and review. The description describes the state of the location and specific information on the location. The location shows the location location on maps so that users can easily go 
to the selected location with the help of maps. Review shows comments about users who have visited the location. The Home menu itself consists of the following eight features that describe on Table 1:

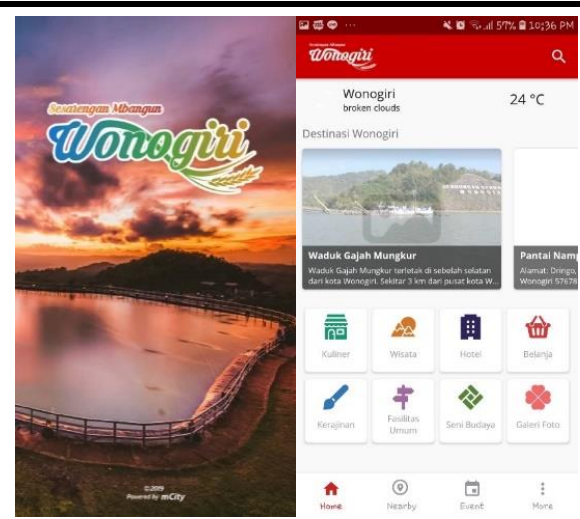

Source: Mobile City Application

Figure 1. General Features of Mobile City Application

Table 1 Description of General Features in Mobile City Application

\begin{tabular}{|c|c|}
\hline Feature & Description \\
\hline Culinary & $\begin{array}{l}\text { Culinary features provide information about the location of culinary tourism that } \\
\text { can be found in the district / city. There are one or several categories in this feature } \\
\text { depending on the district / city in question. }\end{array}$ \\
\hline Tourism & $\begin{array}{l}\text { Travel features generally provide information about the location of tourism in the } \\
\text { Regency / city. There are one or several categories in this feature depending on the } \\
\text { district / city in question. In general, the categories in this feature divide tourist } \\
\text { destinations into Artificial Nature and Tourism. Descriptions found in each location } \\
\text { vary including the history of the establishment, the price of admission tickets, } \\
\text { opening hours, and a brief description of tourist locations. }\end{array}$ \\
\hline Hotels & $\begin{array}{l}\text { This feature provides information about the location of hotel that located in the } \\
\text { district / city. There are one or several categories in this feature depending on the } \\
\text { district / city in question. Descriptions that are in are as varied as address, } \\
\text { telephone number, and rental price. }\end{array}$ \\
\hline Shopping & $\begin{array}{l}\text { This feature provides information about shopping locations in a district / city. } \\
\text { There are one or several categories in this feature depending on the district / city in } \\
\text { question. }\end{array}$ \\
\hline Crafts & $\begin{array}{l}\text { This feature provides information about typical crafts that can be obtained in a } \\
\text { district / city. There are one or several categories in this feature depending on } \\
\text { the district / city in question. }\end{array}$ \\
\hline Public & This feature provides information about the locations of public facilities in a district \\
\hline Facilities & $\begin{array}{l}\text { / city can be in the form of health facilities, education, government, and so on. } \\
\text { There are one or several categories in this feature depending on the district / city in } \\
\text { question. }\end{array}$ \\
\hline $\begin{array}{l}\text { Cultural } \\
\text { Arts }\end{array}$ & $\begin{array}{l}\text { This feature provides information about arts and culture in a district / city. There } \\
\text { are one or several categories in this feature depending on the district / city in } \\
\text { question. }\end{array}$ \\
\hline $\begin{array}{l}\text { Photo } \\
\text { Gallery }\end{array}$ & $\begin{array}{l}\text { This feature displays photos uploaded by users related to the locations they visit in } \\
\text { certain districts / cities. Other users can also give likes or comments to uploaded } \\
\text { photos and publish photos to other social media accounts. If the user wants to } \\
\text { upload photos, he must first connect with Facebook. }\end{array}$ \\
\hline
\end{tabular}


The Nearby menu on the initial display shows the closest location around us when in a particular district / city. so that it can be used as one of the considerations where to go when in the district / city. The Event menu displays a calendar and on the calendar there is information about the events that will be held in the district / city. The last menu is more where it contains travel notes and settings about the application. There are five features, namely travel journals that contain travel records, then my favorite which contains favorite locations in the district / city. Rate it to give an assessment related to the application. Setting feature to set the language used in the application. Whereas About the Application is a feature that explains briefly about the application and its management. The above features are common features found in the city mobile application. However, the features in the mobile city application can be developed according to the needs and desires of the community and some stakeholders. In example on Figure 2 there are some additional features that developed.

Source: Mobile City Application

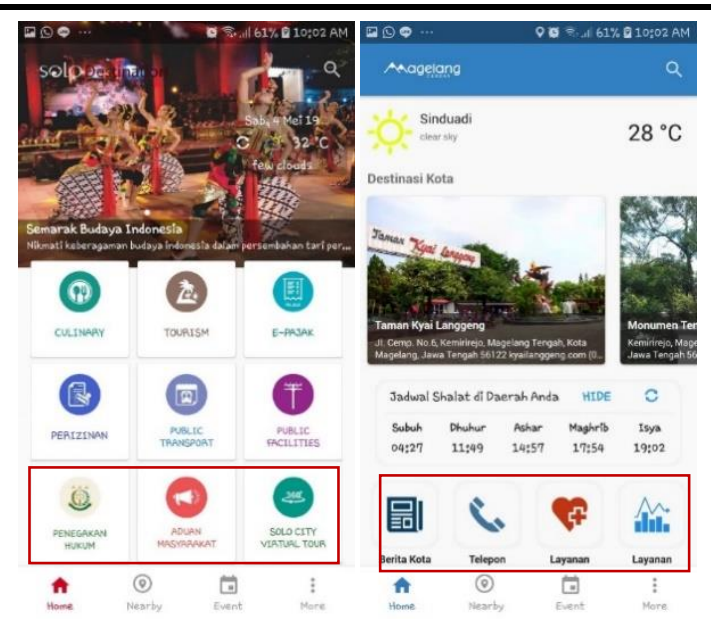

Figure 2. Additional Features on Mobile City Application

\section{Comparison of Features between Mobile City Application}

The addition of features is not only owned by Surakarta City and Magelang City. But some additional features also exist in other districts / cities. Therefore this study also examines the different features between applications. The difference between applications applied in the Regency / City is an additional feature or feature display. Here is a comparison of additional features in the Mobile City application that have similarities. Assessment is done using descriptive statistics to explain the data as it is, to facilitate explanation. Data will be represented by numbers as follows on Table 2 :

Table 2 Scoring Function of Mobile City Features.

\begin{tabular}{cl}
\hline SCORE & \multicolumn{1}{c}{ MEANS } \\
\hline 1 & $\begin{array}{l}\text { There's Feature, but the one primer function can't work consistently according to } \\
\text { expected output. }\end{array}$ \\
2 & $\begin{array}{l}\text { There's Feature, but there's one support function can't work according to expected } \\
\text { output and disturb the normal use, }\end{array}$ \\
3 & $\begin{array}{l}\text { There's Feature, but there's one support function can't work but it doesn't matter. } \\
4\end{array}$ \\
\hline
\end{tabular}


The data that be used to answer the two objectives are application features in each district / city, so the data to be explained is nominal data that has qualitative values and is not bound by sequence and level. Values 1,2,3 and 4 are not levels, but are symbols to make it easier to make comparisons between application features. Primary function is the main function of a feature or function that is directly related to existing features, such as on tourism features, then the primary function must display information about the location on the map. While the support function is a function that supports the primary function. For example in the tourism features, the support function is a description column, photos, comments, likes, and so on.

Comparison of moble city applications in each district / city aims to see the development of each application in each district / city. If the value is high, then the development carried out will be higher. Districts / cities that have the highest scores of General Features are Kota Pariaman, Kota Surakarta, and Kota Yogyakarta with the total value of the common features they have is 80 . This is a perfect value which means that all the three general features of the City function very well. Unlike other districts / cities that have a value of $>80$ which means that the district / city does not have complete general features or the feature has not functioned properly. The regency / city that has the lowest feature is Rembang Regency with a value of 56. Many features in Rembang Regency have a value of 1 , which means that the feature cannot be used.

The districts / cities that have the highest score for special features are Surakarta City with a value of 74 . The city of Surakarta almost has all the special features available. Thus the City of Surakarta excels in general features and special features that indicate that the government and OPD are developing applications to the fullest. There are 5 districts / cities that do not have special features, which means that the application owned by the district / city is still limited to the general features that come from Gamatechno. If represented by a chart, it can be seen in figure 3 :

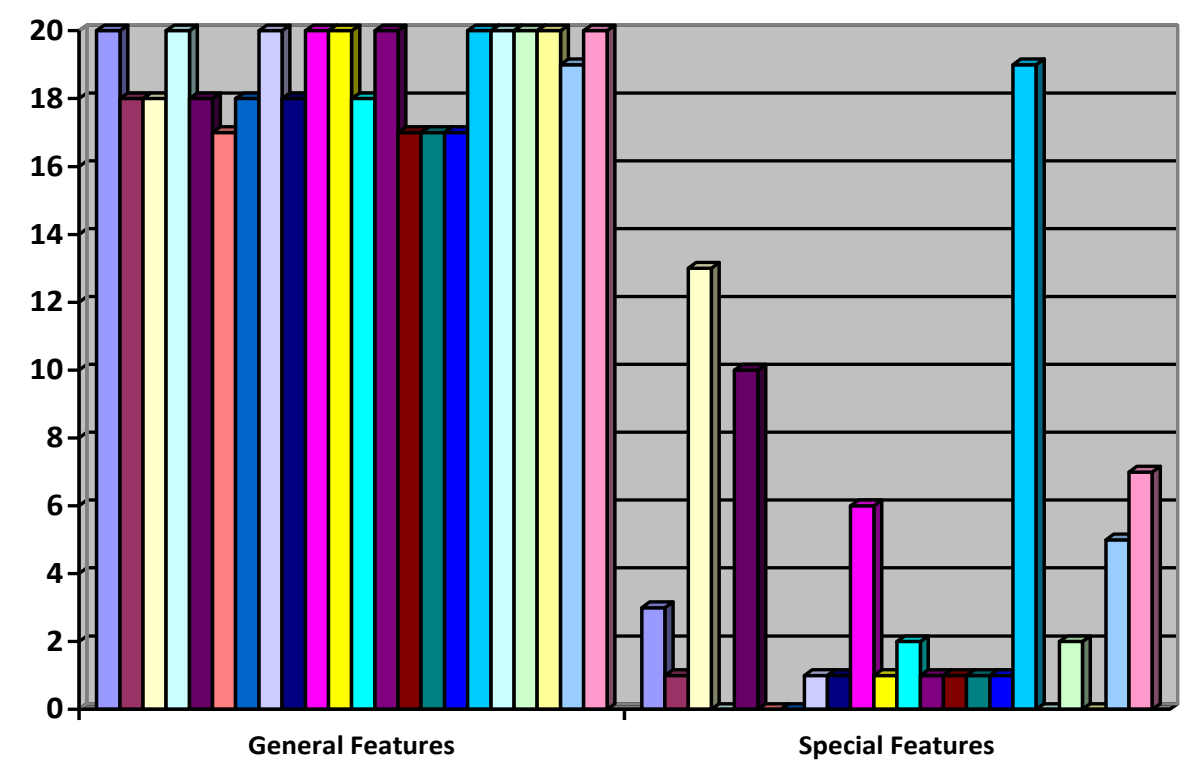

\begin{tabular}{|l|}
\hline$\square$ Kabupaten Lebong \\
$\square$ Kota Batu \\
$\square$ Kota Magelang \\
$\square$ Kota Pariaman \\
$\square$ Kabupaten Kudus \\
$\square$ Kota Denpasar \\
$\square$ Kabupaten Magelang \\
$\square$ Kota Palembang \\
$\square$ Kabupaten Kendal \\
$\square$ Kabupaten Rokan Hulu \\
$\square$ Kabupaten Belitung Timur \\
$\square$ Kabupaten Sleman \\
$\square$ Kabupaten Batubara \\
$\square$ Kabupaten Demak \\
$\square$ Kabupaten Sragen \\
$\square$ Kabupaten Rembang \\
$\square$ Kota Surakarta \\
$\square$ Kabupaten Purbalingga \\
$\square$ Kabupaten Karanganyar \\
$\square$ Kabupaten Wonogiri \\
$\square$ Kota Tangerang Selatan \\
\hline
\end{tabular}

Source: Mobile City Application

Figure 3. Percentage of Scoring Mobile City Application 
Figure 3 shows the percentage assessment of the features of a mobile city application. viewed from 22 regencies / cities that use the mobile city application, they are still dominant in general features, which means there are not many special features applied. Surakarta City is the city that has the highest special features. It mean that Surakarta City has more complete features than the others.

\section{Rank of Mobile City Application each district/city}

The mobile city application in each district / city has different features. The more complete features of the application, the application is getting better. Based on the results of the simple scoring that amount the value of general and special features, it is found that the Mobile City application that has the most complete features is Surakarta City with a total value of 154. The lowest is Rembang Regency with a value of 57 . The difference in features in the city mobile application is due to initial requests from Regency / City government regarding the features to be displayed on the mobile city application and based on developments made by the government after the application was launched. The more features it will get the better and indicates that the application is fully utilized. If sorted according to rank, the results are display on Table 3 :

Table 3 Rank of Features

\begin{tabular}{clc}
\hline Ranking & \multicolumn{1}{c}{ City/Regency } & Value \\
\hline 1 & Surakarta & 154 \\
2 & Magelang & 121 \\
3 & Yogyakarta & 108 \\
4 & Kudus & 107 \\
5 & Rokan Hulu & 101 \\
6 & Tangerang Selatan & 96 \\
7 & Lebong & 90 \\
8 & Karanganyar & 86 \\
9 & Palembang & 81 \\
10 & Pariaman and Sleman & 80 \\
11 & Belitung Timur, Purbalingga, Wonogiri & 78 \\
12 & Kendal & 76 \\
13 & Batu & 74 \\
14 & Magelang & 72 \\
15 & Batu Bara & 68 \\
16 & Demak & 67 \\
17 & Sragen and Denpasar & 66 \\
18 & Rembang & 57 \\
\hline
\end{tabular}

\section{The Implementation of Mobile City Application in Surakarta (Solo Destination)}

The selection of Surakarta City for the application of the mobile city application is because the mobile city application of Surakarta City has the highest number of features, namely 34 . The Surakarta city mobile city application is called Solo Destination. This application is fully managed by the Statistics Informatics Service and Surakarta City Coding. The city of Surakarta in 2018 received an award from the Ministry of Communication and Information of the Republic of Indonesia as one of the cities that has moved towards smart city, which is a program of the Ministry of Communication and Information of the Republic of Indonesia which embodies 100 smart city cities in Indonesia (Kementrian Kominfo RI, 2018).

The Solo Destination application was created in 2014. The initiative to make the Solo Destination application emerged when the Surakarta City government was making a 
Surakarta city smart city master plan. The making of a smart city master plan in Surakarta City was assisted by Gamatechno as their consultant. One result of the consultation by Gamatechno was the making of an application which was finally approved by the Surakarta city government. The process of making an application is done through an auction process to get a company that provides application creation services. The auction process was won by the Gamatechno company so that the Solo Destination application was created by Gamatechno through mobile city which is a city application product launched by Gamatechno. Surakarta City uses the city mobile application service, Cloud.

The decision to develop the Surakarta City towards smart city and the making of the Solo Destination application is the people's demand for easy and transparent public services so that the community can monitor the performance of the local government. In addition, the community also wants their aspirations to be heard by the local government so that the local government can follow up on the aspirations of the community. This is also mentioned in Presidential Instruction No. 3 of 2003 concerning National EGovernment Development Policy and Strategy. The management of the Solo Destination application has been fully held by the Office of Statistics Informatics and Surakarta City Coding. But for the fulfillment of feature content in the application, the Office of Information Communication of Statistics and Surakarta City coding requires the assistance of a related Regional Device Organization (OPD). An example is the Tourism feature. The Tourism feature has four features in it, namely Solo Travel Plan, Tourism, Hotels and Shopping. This feature provides information about tourist locations and supporting tourist sites in Surakarta. The data needed so that this feature can provide tourist locations and tourist supporting locations in Surakarta, the Office of Information Communication of Statistics and Surakarta City Coding needs the assistance of the relevant OPD, namely the Surakarta City Tourism Office. Information needed in these features is a photo, location position in maps, description of location such as price, number of rooms, and others. The process of collecting data is the Surakarta Statistic and City Library Communication Office and Surakarta City Tourism Office assisted by several related organizations such as the Indonesian Hotels and Restaurants Association (PHRI) in Surakarta City. PHRI then provides data in accordance with the format provided by the Office of Statistics Informatics and Surakarta City coding in the form of photos, location positions, and descriptions. Then the Statistical Information Communication Office and Surakarta City Coding upload the data into the Tourism feature.

Regional Device Organizations (OPD) can request that additional features in Solo Destination match the needs of the OPD. An example is the Office of Cooperatives, Small and Medium Enterprises of the City of Surakarta, requesting a feature in the form of MSMEs that displays the choice of MSME products in Surakarta City which is currently still in the development stage. Another example is the Office of Population and Civil Registration of the City of Surakarta, which asks for training registration. The Office of Information Communication of Statistics and Surakarta City Coding will later make the features desired by the Population and Civil Registration Service, but for the design and format of registration comes from the related OPD. So that if an OPD wants to ask for help from the Office of Statistics Informatics and Surakarta City Coding to add features in the Solo Destination, the OPD is obliged to provide any format that needs to be displayed on the Solo Destination. In example was on Figure 4 that new features create based on request.

The Solo Destination application is also connected with other applications and related websites. Related applications include the application of Dukcapil Dalam Genggaman, Info Lalin Solo, SiDjaka Dishub Solo, Solo E-Office, and moovit. Whereas the website is related to the Solo Destination application such as the local government website, Surakarta City DataGo website, and others. The purpose of the local government to 
associate the Solo Destination application with other applications is because the local government wants to make the Solo Destination application the only application that is remembered by the community and becomes a portal to access other applications or websites related to Surakarta City government. The Solo Destination application continues to be promoted by every Surakarta City Mayor and mayor on various occasions such as at events carried out by the city government and OPD, through magazines, city television, and so on. Based on the incessant introduction of the Solo Destination application in Solo City, downloaders of the Solo Destination application are summarized in Table 4.

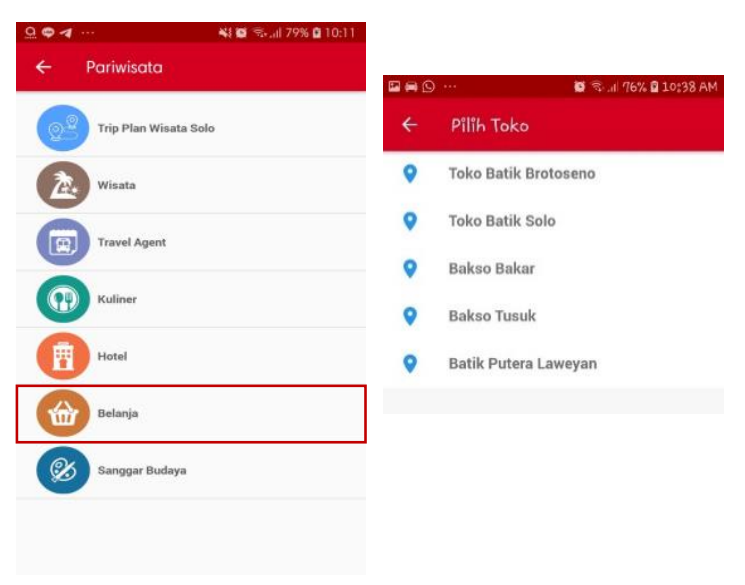

Source: Mobile City Application

Figure 4. Appearance of UMKM Features that early made that include on Shopping Menu.

Table 4 Amount of Solo Destination Application Downloader on 2018

\begin{tabular}{clc}
\hline Number & Month & Downloader \\
\hline 1 & January & 268 \\
2 & February & 277 \\
3 & March & 336 \\
4 & April & 281 \\
5 & May & 204 \\
6 & June & 252 \\
7 & July & 418 \\
8 & August & 374 \\
9 & September & 404 \\
10 & October & 308 \\
\hline
\end{tabular}

Source: Office of Infromation Communication Statistics and Coding of Surakarta City

In addition to the number of downloaders, active users of Solo Destination can also be seen in table 5 . 
Table 5 Amount of Solo Destination Application User on 2018.

\begin{tabular}{clccc}
\hline Number & Month & $\begin{array}{c}\text { Active } \\
\text { User }\end{array}$ & $\begin{array}{c}\text { Average of Application } \\
\text { Access' Time }\end{array}$ & $\begin{array}{c}\text { Amount of Application was } \\
\text { Access (xTimes) }\end{array}$ \\
\hline 1 & January & 1.655 & 2 minutes 30 seconds & 59.780 \\
2 & February & 1.539 & 2 minutes 12 seconds & 45.508 \\
3 & March & 1.729 & 2 minutes 21 seconds & 54.129 \\
4 & April & 1.550 & 2 minutes 25 seconds & 48.168 \\
5 & May & 1.488 & 2 minutes 26 seconds & 45.520 \\
6 & June & 1.555 & 2 minutes 31 seconds & 42.176 \\
7 & July & 1.795 & 2 minutes 25 seconds & 61.455 \\
8 & August & 1.864 & 2 minutes 25 seconds & 60.563 \\
9 & September & 1.729 & 2 minutes 29 seconds & 61.484 \\
10 & October & 1.573 & 2 minutes 10 seconds & 90.682 \\
\hline
\end{tabular}

Source: Office of Infromation Communication Statistics and Coding of Surakarta City

The number of downloaders and users of Solo Destination is the result of city government promotion and OPD related to the Solo Destination application. The feature that is often used by the community is the complaint feature. Communities actively report on situations in the field that are not appropriate. Such as illegal levies on the market, careless parking, and so on. This complaint feature (Figure 5) provides a choice of complaints such as illegal levies, permits, community welfare, and the total choice of complaints topics as much as 73. Public complaints will go directly to the OPD or related bodies such as the website complaint topic, then the complaint will enter the Communication Service Statistics and Surakarta City Coding which will then be followed up by the OPD. The community can monitor the extent to which their complaints are followed up. If a complaint has been followed up, there will be a green sign and written Respond. If the complaint is still not followed up it will be blue and read Process.

Source: Mobile City Application

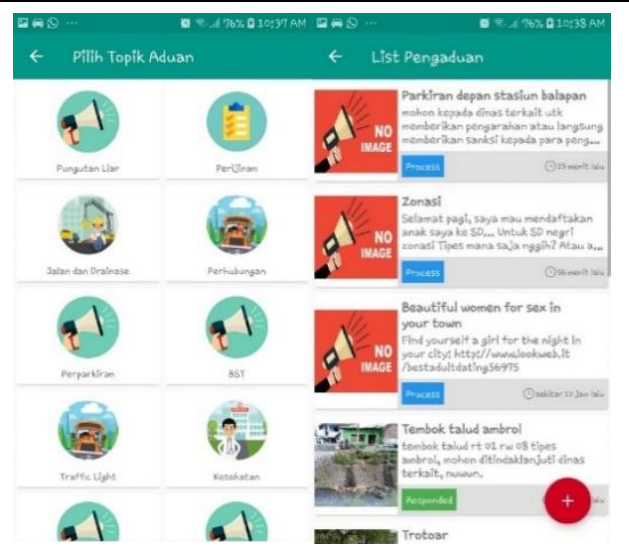

Figure 5. Appearance of Layanan Pengaduan Feature in Solo Destination.

This Solo Destination application is considered to be able to create the City of Surakarta as a Smart City that can provide excellent service to the community without leaving the culture of the community in accordance with the Smart City principle that is applied in Surakarta, namely Smart Culture Smart Urban Services. The hope with the rapid development of ICT in Surakarta City does not eliminate the existing culture in Surakarta City. Therefore the Surakarta City government did not implement ICT in several fields such as at the kelurahan level. The City Government does not provide e-kelurahan. E- 
kelurahan is a technology that provides community population services at the kelurahan level. The elimination of the e-kelurahan is intended so that the community still mingles with fellow citizens and the village / kelurahan government. So that it is expected that the relationship process is still maintained. That's the concept of Smart Culture Smart Urban Services that the Surakarta City government wants.

The constraints that exist in managing the Solo Destination lie in the human resources needed (HR). The intended HR is human resources who understand the ICT field and are able to operate an application. In addition, the rate of transfer of employees in government is quite fast. So that there are often employee changes. This results in HR holding applications often changing and it is not uncommon for people who are placed to not understand the application so they have to teach starting from the beginning.

\section{CONCLUSION}

The Mobile City application uses a Location-Based Services (LBS) system that has the ability to utilize the location of mobile devices, so they can find out the location of a tourist destination or public facility. This resulted in the main features of the Mobile City application relating to the location of tourism and public facilities. While additional features are the development of each district / city. Comparison between features in each district / city is caused by the development of each district / city so that the functions and outputs of each feature in each application are different even though the feature names are the same.

The city that has the most complete application is Surakarta City based on the results of ranking mobile city applications in each district / city based on the features it has with a total of 34 features. Solo Destination Application is a mobile city application that is implemented in Surakarta City which is fully managed by the Office of Statistics Informatics and Surakarta City Coding which is assisted by all OPDs in collecting data. The feature that is often used is the feature of the Complaints Society, which the community actively participates in developing Surakarta City through input and complaints from the community.

This paper only explore about mCity Application which is an example of smart city application. Every smart city is a dynamic and complex system that make any City/Regency can't have the same application. The ICT aspect is key for the development of smart city applications. Today, researchers have investigated ICT that can build smart city application such as IoT (Alam et al., 2017), big data analytics (Bibri \& Krogstie, 2017), security management systems (Li \& Shahidehpour, 2017), and geographic information systems (Aina, 2017), and etc. So for the next research it could more focus to explore an smart city applications in detail such as the completeness on big data and the geographic information systems. On the last research that Mcall did (McCall, Jim A and Richards, Paul $\mathrm{K}$ and Walters, 1977) it analysis about the software quality such as Product operational characteristics (Product Operation), Product Transition is the application's ability to change which includes: Product revision that assesses the ability of the application to adapt includes: a) Maintainability, namely the ability to find and repair damaged applications; b) Flexibility (Flexibility) regarding changes that are needed at any time according to certain circumstances; c) Testability the ability to be tested to validate application requirements and ensure that the program can perform functions as expected. Indonesia has an problem about the accesbility of data. It can be barriers to researchers or developers to develop an application or make some research about big data and Geoinformation and Communication Technology (GeoICT) and how to create or develop an application. So for fututre research need to search more studies that required for policy development about 
smart city and ICT application to developing smart cities with big data and GeoICT because it can make smart sustainable cities.

\section{REFERENCES}

Aguilera, U., Peña, O., Belmonte, O., \& López-de-Ipiña, D. (2017). Citizen-centric data services for smarter cities. Future Generation Computer Systems, 76(October 2017), 234-247. https://doi.org/10.1016/j.future.2016.10.031

Ahmadi-Assalemi, G., Al-Khateeb, H., Epiphaniou, G., \& Maple, C. (2020). Cyber Resilience and Incident Response in Smart Cities: A Systematic Literature Review. Smart Cities, 3(3), 894-927. https://doi.org/10.3390/smartcities3030046

Aina, Y. A. (2017). Achieving smart sustainable cities with GeoICT support: The Saudi evolving smart cities. Cities, 71(May), 49-58. https://doi.org/10.1016/j.cities.2017.07.007

Alam, F., Mehmood, R., Katib, I., Albogami, N. N., \& Albeshri, A. (2017). Data Fusion and IoT for Smart Ubiquitous Environments: A Survey. IEEE Access, 5, 9533-9554. https://doi.org/10.1109/ACCESS.2017.2697839

Bibri, S. E., \& Krogstie, J. (2017). ICT of the new wave of computing for sustainable urban forms: Their big data and context-aware augmented typologies and design concepts. Sustainable Cities and Society, 32, 449474. https://doi.org/10.1016/j.scs.2017.04.012

Daniel, S., \& Doran, M.-A. (2013). geoSmartCity. 65. https://doi.org/10.1145/2479724.2479738

Hapsari, A. N., \& Rachmawati, R. (2018). Pemanfaatan Aplikasi Lapor Sleman Sebagai Pelayanan Pengaduan di Kabupaten Sleman. Jurnal Bumi Indonesia, Volume 7,.

Kementrian Kominfo RI. (2018). Gerakan Menuju $100 \quad$ Smart City. https://aptika.kominfo.go.id/2018/11/gerakan-menuju-100-smart-city/

Li, Z., \& Shahidehpour, M. (2017). Deployment of cybersecurity for managing traffic efficiency and safety in smart cities. Electricity Journal, 30(4), 52-61. https://doi.org/10.1016/j.tej.2017.04.003

McCall, Jim A and Richards, Paul K and Walters, G. F. (1977). Factors in software quality, volumes I, II, and III. US Rome Air Development Center Reports, US Department of Commerce, USA, I(November).

mCity. (2017). Aplikasi Mobile City. Aplikasi Mobile City.

Rachmawati, R. (2012). Population Mobility and Urban Spatial Structure: Does the Use of Information and Communication Technology Matter? Regional Views, 25(January).

Rachmawati, R. (2019). Toward better city management through smart city implementation. Human Geographies, 13(2), 209-218. https://doi.org/10.5719/hgeo.2019.132.6

Rachmawati, R., Ramadhan, E. R., \& Rohmah, A. 'Ainur. (2018). Aplikasi Smart Province "Jogja Istimewa": Penyediaan Informasi Terintegrasi dan Pemanfaatannya. Majalah Geografi Indonesia, 32(1), 14. https://doi.org/10.22146/mgi.31662

Rachmawati, R., Rijanta, R., \& Djunaedi, A. (2015). Location decentralization due to the use of information and communication technology: Empirical evidence from Yogyakarta, Indonesia. Human Geographies, 9(1), 5-15. https://doi.org/10.5719/hgeo.2015.91.1

Radu, L. (2020). smart cities Disruptive Technologies in Smart Cities: A Survey on Current Trends and Challenges. 1022-1038.

Sekretariat Negara. (2003). Instruksi Presiden Nomor 3 Tahun 2003 tentang Kebijakan dan Strategi Nasional Pengembangan e-government. Sekretariat Negara. 